\title{
DNA barcode of Parodontidae species from the La Plata river basin - applying new data to clarify taxonomic problems
}

\author{
Elisangela Bellafronte ${ }^{1}$, Tatiane Casagrande Mariguela ${ }^{2}$, Luiz Henrique Garcia Pereira ${ }^{2}$, \\ Claudio Oliveira ${ }^{2}$ and Orlando Moreira-Filho ${ }^{1}$
}

In the past years, DNA barcoding has emerged as a quick, accurate and efficient tool to identify species. Considering the difficulty in identifying some Parodontidae species from the La Plata basin and the absence of molecular data for the group, we aimed to test the effectiveness of DNA barcoding and discuss the importance of using different approaches to solve taxonomic problems. Eight species were analyzed with partial sequences of Cytochrome c oxidase I. The mean intraspecific K2P genetic distance was $0.04 \%$ compared to $4.2 \%$ for mean interspecific K2P genetic distance. The analyses of distance showed two pairs of species with K2P genetic divergence lower than $2 \%$, but enough to separate these species. Apareiodon sp. and A. ibitiensis, considered as the same species by some authors, showed $4.2 \%$ genetic divergence, reinforcing their are different species. Samples of $A$. affinis from the Uruguay and Paraguay rivers presented $0.3 \%$ genetic divergence, indicating a close relationship between them. However, these samples diverged 6.1\% from the samples of the upper Paraná River, indicating that the latter represents a potentially new species. The results showed the effectiveness of the DNA barcoding method in identifying the analyzed species, which, together with the morphological and cytogenetic available data, help species identification.

Nos últimos anos o DNA barcoding surgiu como uma ferramenta rápida, precisa e eficiente para identificar espécies. Considerando a dificuldade na identificação de algumas espécies de Parodontidae da bacia do rio da Prata e da ausência de dados moleculares para o grupo, testamos a eficácia do código de barras de DNA e discutimos a importância do uso de diferentes abordagens para resolver problemas taxonômicos. Oito espécies foram analisadas com sequencias parciais do gene citocromo c oxidase I. A distância genética média K2P intraespecífica foi de $0,04 \%$ comparado com 4,2\% para distância genética média K2P interespecífica. As análises de distância mostraram dois pares de espécies com divergência genética K2P inferior a 2\%, mas o suficiente para separar estas espécies. Apareiodon sp. e A. ibitiensis, consideradas a mesma espécie por alguns autores, mostraram 4,2\% de divergência genética, confirmando serem espécies diferentes. Amostras de A. affinis dos rios Uruguai e Paraguai apresentaram $0,3 \%$ de divergência genética, indicando um maior grau de relação entre elas, no entanto, esses exemplares divergiram em $6,1 \%$ em relação aos exemplares do alto rio Paraná, o que indica que estes últimos representam uma espécie potencialmente nova. Os resultados mostraram a eficácia do método de DNA barcoding na identificação das espécies analisadas, os quais, em conjunto com os dados morfológicos e citogenéticos disponíveis auxiliam na identificação inequívoca das espécies.

Key words: Apareiodon, COI gene, Cytogenetics, Fish identification, Morphology.

\section{Introduction}

During the past two centuries, about 1.7 million species were described by taxonomists, but it is known that this number is still quite reduced considering the biological diversity present on Earth (Blaxter, 2003; Wilson, 2003). Although biological research depends greatly on species diagnosis, traditionally performed by taxonomists (most based on analyses of morphological characters), other tools have been created to assist in this difficult task (Hebert et al., 2003).
Given the lack of specialists in many groups and geographic areas and the insufficient funds for taxonomic studies (Godfray, 2002; Mallet \& Willmott, 2003; Pires \& Marinoni, 2010), the use of integrated methodologies is increasingly necessary and a great call for the deployment of "Integrative Taxonomy" is actually stronger. According to Dayrad (2005), this new approach involves multiple and complementary perspectives (phylogeography, comparative morphology, genetics, ecology, development, behavior, among others) and has successfully assisted traditional

\footnotetext{
${ }^{1}$ Universidade Federal de São Carlos (UFSCar), Departamento de Genética e Evolução. Rodovia Washington Luís, km 235, SP 310 , Jardim Guanabara, 13565-905 São Carlos, São Paulo, Brazil. e_bio79@yahoo.com.br(EB), omfilho@ufscar.br(OMF)

${ }^{2}$ Universidade Estadual Paulista (UNESP), Departamento de Morfologia, Instituto de Biociências. Distrito de Rubião Junior S/N, 18618970 Botucatu, São Paulo, Brazil. tatimariguela@gmail.com (TCM), luizhgp_bio@yahoo.com.br(LHGP), claudio@ibb.unesp.br(CO)
} 
morphology in studies on biodiversity (Baker et al., 2003; Marcussen, 2003; Meyer, 2003; Malhotra \& Thorpe, 2004; Gibbs, 2009; Jansen et al., 2009; Chen et al., 2011). Bickford et al. (2007) conveyed that in the past two decades there has been an exponential increase in the identification and recognition of cryptic species with the advancement and use of molecular tools. Examples of such integration are increasingly common in fish, such as in the description of Gymnotus sylvius (Albert et al., 1999), Gymnotus pantanal (Fernandes et al., 2005), Moenkhausia forestii (Benine et al., 2009), and Tetragonopterus carvalhoi (Melo et al., 2011). These examples are particularly relevant, since they refer to new species from quite complex fish genera which were described after the accumulation of morphological and molecular evidence, demonstrating the singularity of the studied samples regarding their respective counterparts.

Among the molecular methodologies used for species identification, the DNA barcoding emerges as a quick, accurate and efficient tool, and, as such, contributes greatly to taxonomic studies and biodiversity researches (Hebert \& Gregory, 2005; Hajibabaei et al., 2007). The basic principle that sustains the DNA barcoding methodology is related to the premise that a short standardized DNA sequence - Cytochrome $c$ Oxidase I (COI), can distinguish species through the interspecific genetic variation, which exceeds intraspecific variation (Hajibabaei et al., 2007; Toffoli et al., 2008). Although the use of DNA barcoding is very controversial for using a single mitochondrial gene for species identification, it is believed to be a powerful tool (Ward et al., 2009). Many studies have demonstrated its effectiveness in identifying species in different animal groups (Folmer et al., 1994; Hebert et al., 2004; Barrett \& Hebert, 2005; Hajibabaei et al., 2006), including fish (Ward et al., 2005; Hubert et al., 2008 Persis et al., 2009; Pereira et al., 2010).

Parodontidae is a group of small-sized fish distributed primarily throughout South America, occurring in the eastern half of Panamá, on the Pacific and Caribbean coasts of Colombia and the Pacific coast of Ecuador, in the Orinoco and Amazonas basins, in the Guianas and southwards, including the La Plata basin (Roberts, 1974). It is a relatively small family that includes three genera: Parodon, Apareiodon, and Saccodon (Pavanelli, 2003). Cytogenetic studies on Parodontidae reveal that although the species of this family show a predominant diploid number of 54 chromosomes, the karyotypic macrostructure and genomic structure are very diversified, with distinct sex chromosome systems (MoreiraFilho et al., 1980; Jesus \& Moreira-Filho, 2000a; Vicari et al., 2006; Rosa et al., 2006; Bellafronte et al., 2009; 2011), structural polymorphism (Jorge \& Moreira-Filho, 2000, 2004), interspecific and intraspecific variation in the number and position of nucleolus organizer regions on chromosomes (Moreira-Filho et al., 1984; Vicente et al., 2001; Bellafronte et al., 2009; 2011) and interspecific differences in the distribution of distinct satellite DNA families (Vicente et al., 2003; Bellafronte et al., 2011; Schemberger et al., 2011).

When comparing results from different techniques (morphological characterization and cytogenetics), it is observed that some species in the Parodontidae family are particularly difficult to identify. Thus, considering this difficulty, the absence of molecular data for the group and given the importance and complexity of the fish fauna of the La Plata River basin, the authors aimed to test the effectiveness of DNA barcoding to identify Parodontidae species present in the La Plata River basin and discuss the importance of using "integrative taxonomy", i.e., different approaches on the resolution of taxonomic problems.

\section{Materials and Methods}

Species collection. Specimens of seven known and a putative new species of Parodontidae were collected in eight distinct localities along the La Plata basin, including the Uruguay, Paraguay, and Paraná River basins (Table 1, Fig. 1). Fresh tissue samples were taken and preserved in $-20^{\circ} \mathrm{C}$ absolute ethanol. Vouchers specimens were deposited in taxonomic collections (Table 1) and identified with the assistance of taxonomists.

Extraction, PCR amplification and DNA sequencing. Genomic DNA extraction was performed from solid tissues (liver, muscle or fin) using the phenol: chloroform extraction technique (Sambrook et al., 1989). Partial sequences of the cytochrome c oxidase I gene (COI) were amplified with the Fish F1 and Fish R1 primers (Ward et al., 2005). The PCR reaction contained the final volume of 25,0 $\mu$ l, including 2,5 $\mu 110 x$ PCR Buffer, $0,7 \mu 1 \mathrm{MgCl}_{2}(50 \mathrm{mM}), 0,5 \mu l$ of each primer $(10 \mathrm{mM}), 4,0 \mu \mathrm{dNTPs}$ $\operatorname{mix}(1,25 \mathrm{mM}), 0,2 \mu 1 \mathrm{Taq}$ polymerase (Invitrogen), 1,0 $\mu 1$ template DNA $(50 \mathrm{ng} / \mu \mathrm{l})$ and $15,6 \mu \mathrm{l}$ ultrapure water. Amplifications were made using the cycle that corresponds to an initial step of $2 \mathrm{~min}$ at $94^{\circ} \mathrm{C}$, followed by 35 cycles of 0,5 min at $94^{\circ} \mathrm{C}, 0,5 \mathrm{~min}$ at $54^{\circ} \mathrm{C}$ and $1 \mathrm{~min}$ at $72^{\circ} \mathrm{C}$, followed by 10 min at $72^{\circ} \mathrm{C}$. PCR products were visualized on $1 \%$ agarose gel and purified by the Illustra GFX PCR DNA and Gel Band Purification kit (GE Healthcare Life Sciences). Sequencing reactions of both DNA strands were performed using the BigDye ${ }^{\circledR}$ Terminator v3.1 Cycle Sequencing Kit and sequencing was performed on the automatic sequencer $\mathrm{ABI}$ 3730 DNAAnalyzer (Applied Biosystems).

Data Analysis. Individual sequences of each species were initially analyzed using Bioedit 5.0.9 software (Hall, 1999) and a consensus sequence was obtained for each DNA segment for each species. All the sequences were aligned with the ClustalW algorithm integrated in the software DAMBE (Xia $\&$ Xie, 2001). Genetic distances were calculated using the distance model Kimura-2-parameter (K2P) (Kimura, 1980). The Neighbor-joining (NJ) dendrogram with the genetic K2P distances was made to provide a representative graphic of the divergence pattern and separation among species (Saitou $\&$ Nei, 1987). The genetic distance analyses and the dendrogram were made with the software MEGA 5.01 (Tamura et al., 2011). For the pairs of species that presented interspecific divergence values lower than $2 \%$, the nucleotide diagnostic (ND) approach was applied. The NDs were manually 
Table 1. List of specimens used in barcoding analyses and their collection data.

\begin{tabular}{|c|c|c|c|}
\hline Species & Localities & Coordinates & Vouchers \\
\hline A. affinis & $\begin{array}{c}\text { Cuiabá river, Paraguay basin } \\
\text { (MT) }\end{array}$ & $\begin{array}{l}15^{\circ} 37^{\prime} 52.07^{\prime \prime} \mathrm{S} \\
56^{\circ} 04^{\prime} 55.14 ” \mathrm{~W}\end{array}$ & $\begin{array}{c}\text { Núcleo de Pesquisas em Limnologia, Ictiologia e Aquicultura (Nupelia), } \\
\text { Universidade Estadual de Maringá, Brasil (NUP 12151) }\end{array}$ \\
\hline A. affinis & $\begin{array}{c}\text { Arroyo Chimiray river, } \\
\text { Uruguay basin (Argentina) }\end{array}$ & $\begin{array}{c}28^{\circ} 05^{\prime} 29.8^{\prime \prime} \mathrm{S} \\
55^{\circ} 42^{\prime} 19.49^{\prime \prime} \mathrm{W}\end{array}$ & $\begin{array}{c}\text { Núcleo de Pesquisas em Limnologia, Ictiologia e Aquicultura (Nupelia), } \\
\text { Universidade Estadual de Maringá, Brasil (NUP 12154) }\end{array}$ \\
\hline A. affinis & $\begin{array}{l}\text { Passa-Cinco river, Upper } \\
\text { Paraná basin (SP) }\end{array}$ & $\begin{array}{l}22^{\circ} 25^{\prime} 26^{\prime \prime} \mathrm{S} \\
47^{\circ} 41^{\prime} 56^{\prime \prime} \mathrm{W} \\
\end{array}$ & Museu Nacional do Rio de Janeiro (MNRJ: 31428) \\
\hline A. ibitiensis & $\begin{array}{l}\text { Passa-Cinco river, Upper } \\
\text { Paraná basin (SP) } \\
\end{array}$ & $\begin{array}{l}22^{\circ} 25^{\prime} 26^{\prime \prime} \mathrm{S} \\
47^{\circ} 41^{\prime} 56^{\prime \prime} \mathrm{W}\end{array}$ & Museu Nacional do Rio de Janeiro, Brasil (MNRJ32771 ) \\
\hline A. piracicabae & $\begin{array}{l}\text { Passa-Cinco river, Upper } \\
\text { Paraná basin (SP) }\end{array}$ & $\begin{array}{l}22^{\circ} 25^{\prime} 26^{\prime \prime} \mathrm{S} \\
47^{\circ} 41^{\prime} 56^{\prime \prime} \mathrm{W}\end{array}$ & $\begin{array}{c}\text { Núcleo de Pesquisas em Limnologia, Ictiologia e Aquicultura (Nupelia), } \\
\text { Universidade Estadual de Maringá, Brasil (NUP 12149) }\end{array}$ \\
\hline A. vitattus & $\begin{array}{l}\text { Jordão river, Iguaçu basin } \\
\text { (PR) }\end{array}$ & $\begin{array}{l}25^{\circ} 42^{\prime} 31^{\prime \prime} \mathrm{S} \\
51^{\circ} 53^{\prime} 53^{\prime \prime} \mathrm{W}\end{array}$ & $\begin{array}{c}\text { Núcleo de Pesquisas em Limnologia, Ictiologia e Aquicultura (Nupelia), } \\
\text { Universidade Estadual de Maringá, Brasil (NUP 1950) }\end{array}$ \\
\hline A. vladii & $\begin{array}{l}\text { Piquiri river, Upper Paraná } \\
\text { basin (PR) }\end{array}$ & $\begin{array}{c}25^{\circ} 01^{\prime} 40.9^{\prime \prime} \mathrm{S} \\
52^{\circ} 27^{\prime} 32.8^{\prime \prime} \mathrm{W}\end{array}$ & $\begin{array}{c}\text { Núcleo de Pesquisas em Limnologia, Ictiologia e Aquicultura (Nupelia), } \\
\text { Universidade Estadual de Maringá, Brasil (NUP 3375) }\end{array}$ \\
\hline Apareiodon sp. & $\begin{array}{l}\text { Verde river, Upper Paraná } \\
\text { basin (PR) }\end{array}$ & $\begin{array}{l}25^{\circ} 04^{\prime} 35.59^{\prime \prime} \mathrm{S} \\
50^{\circ} 04^{\prime} 02.10^{\prime \prime \prime} \mathrm{W}\end{array}$ & $\begin{array}{c}\text { Núcleo de Pesquisas em Limnologia, Ictiologia e Aquicultura (Nupelia), } \\
\text { Universidade Estadual de Maringá, Brasil (NUP 3443) }\end{array}$ \\
\hline P. moreirai & $\begin{array}{l}\text { Sapucaí river, Upper Paraná } \\
\text { basin (SP) }\end{array}$ & $\begin{array}{l}22^{\circ} 40^{\prime} 33.76^{\prime \prime} \mathrm{S} \\
45^{\circ} 41^{\prime} 00^{\prime \prime} \mathrm{W}\end{array}$ & Museu Nacional do Rio de Janeiro, Brasil (MNRJ 22557) \\
\hline P. nasus & $\begin{array}{l}\text { Cuiabá river, Paraguay basin } \\
\text { (MT) }\end{array}$ & $\begin{array}{l}15^{\circ} 34^{\prime} 40.69^{\prime \prime} \mathrm{S} \\
56^{\circ} 09^{\prime} 58.73 ” \mathrm{~W}\end{array}$ & Museu Nacional do Rio de Janeiro, Brasil (MNRJ29787) \\
\hline
\end{tabular}

identified with the software Bioedit 5.0.9 (Hall, 1999). All sequences obtained in this study were deposited in Barcode of Life Data Systems (BOLD).

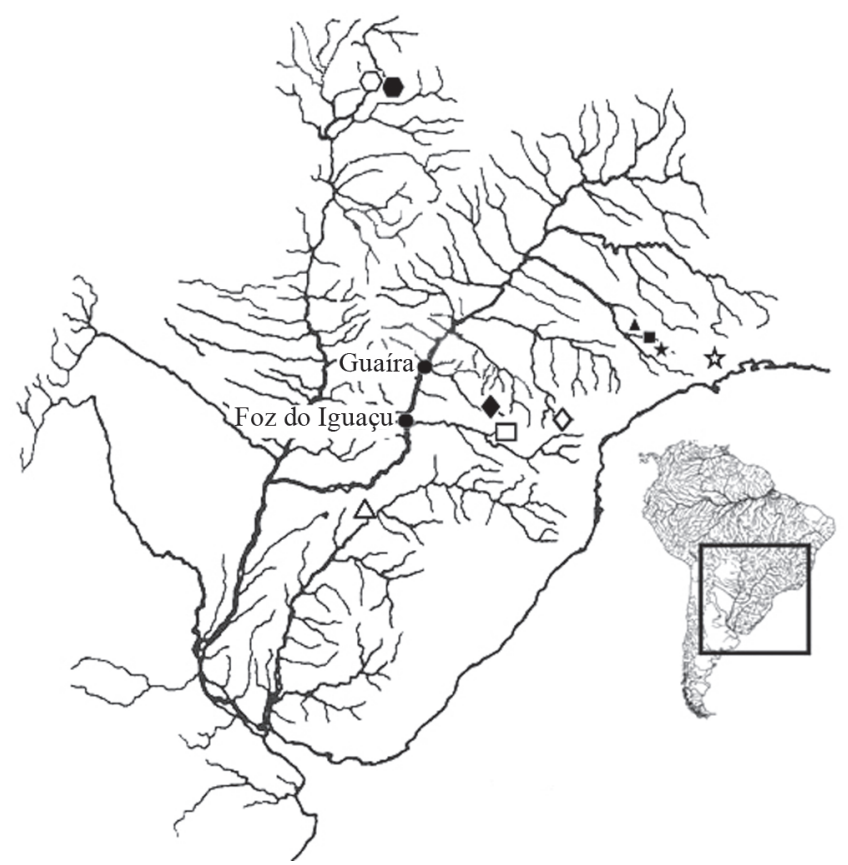

Fig. 1. Map of the La Plata River basin showing the localities of Parodontidae samples used in this study. Empty pentagon: $P$. nasus; full pentagon: $A$. affinis; empty star: P. moreirai; full star: $A$. affinis; empty square: $A$. vittatus; full square: $A$. piracicabae; empty lozenge: Apareiodon sp.; full lozenge: A. vladii; empty triangle: A. affinis; full triangle: A. ibitiensis. The Iguaçu Falls and the Itaipu hydroelectric Power Plant are located in the city of Foz do Iguaçu, PR and the old Seven Falls in the city of Guaíra, PR - shown on the map.

\section{Results}

All species analyzed were represented by more than one specimen (an average of 4.4 specimens per species), totalizing $44 \mathrm{COI}$ sequences with $659 \mathrm{bp}$. The COI sequences obtained were of high quality and the consensus sequence showed no evidence of insertions, deletions or stop codons. All species were discriminated by their barcode sequences. A NeighborJoining tree is presented in Fig. 2. The mean K2P genetic distance within species was $0.04 \%$, comparing to $4.2 \%$ mean interspecific K2P genetic distance (Table 2). The distances between congeners ranged from $0.9 \%$ to $10.7 \%$ among the species of Apareiodon and were of only $0.7 \%$ between the two analyzed species of Parodon (Table 2). Thus, the interspecific variation was 105 times higher on average compared to the intraspecific variation. The genetic distance between the two analyzed genera was $14.1 \%$. Distance analyses showed two pairs of species with K2P genetic divergence lower than $2 \%$, but enough to separate these species (Table 2, Fig. 2). For these pairs of species, the ND approach was applied, showing the presence of five nucleotides for the pair of species $A$. piracicabae and $A$. vittatus, and four for the pair of species $P$. morerai and $P$. nasus (Table 3). The species $A$. affinis showed intraspecific K2P genetic divergence values higher than 2\% (Table 2), splitting into three subgroups, according to the NJ dendrogram obtained, corresponding to their collection points (Fig. 2). The analysis of these subgroups conducted separately showed that the subgroup referring to the upper Paraná River population diverges considerably from the other two $(6.1 \%)$, thus, representing a possible new species (Table 2, Fig. 2).

A table for comparison of different characters used for species identification (chromosomal, molecular, and morphological) was constructed to integrate data of 


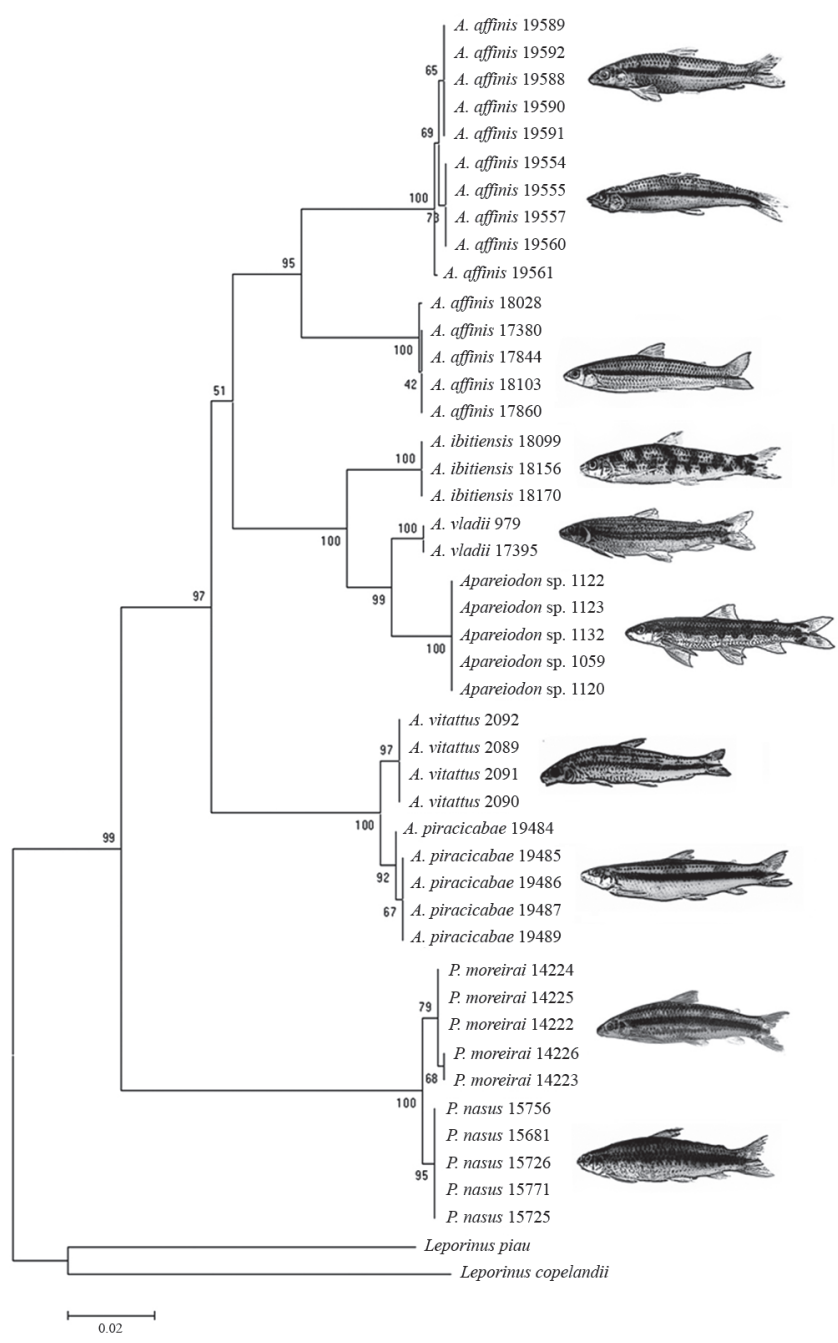

Fig. 2. K2P distance NJ dendrogram showing the nine analyzed species/populations of Parodontidae from the $\mathrm{La}$ Plata River basin.
Parodontidae from the literature and the results obtained here (Table 4). The pair of the species A. ibitiensis + Apareiodon sp. and A. piracicabae $+A$. vittatus are chromosomally and morphologically very similar, however the first pair showed a high genetic divergence $(4.2 \%)$ and the second pair showed a low genetic divergence $(0.9 \%)$. As for the pair of species the P. nasus $+P$. moreirai, although they were very distinct chromosomally and morphologically they showed low genetic divergence $(0.7 \%)$. The samples of $A$. affinis from the Paraguay and Uruguay rivers, morphologically identical to the upper Paraná River population, showed very distinct chromosomal characteristics and high genetic divergence (6.1\%) (Table 4).

\section{Discussion}

For the family studied, the DNA barcoding methodology was very efficient, allowing the correct identification of the seven known and a putative new species of Parodontidae. The mean intraspecific K2P genetic divergence was $0.04 \%$, 105 times smaller than the interspecific divergence, which was $4.2 \%$. These values are consistent with other DNA barcoding studies performed on fish. Ward et al. (2005) discriminated Australian marine fish species that were analyzed with a mean K2P distance of $0.39 \%$ in individuals of the same species compared to $9.93 \%$ in species within the genus, thus showing 25 times more variation among congeneric species than among conspecific individuals. Hubert et al. (2008), studying continental fish from Canada, discriminated $93 \%$ of the species with an average of $0.3 \%$ conspecific distance and $8.3 \%$ congeneric distance, i.e., a difference of 27 times between these two categories. Ward et al. (2009) analyzed the K2P genetic divergence values in 1088 fish species available on BOLD and found conspecific values of $0.3 \%$ and congeneric values of $8.4 \%$, discriminating $97.5 \%$ of the species. Marine fish species from India showed an average $\mathrm{K} 2 \mathrm{P}$ distance of $0.24 \%$ within species and a

Table 2. Nucleotide divergence among species: The highlighted numbers represent K2P differences lower than $2 \%$ between species.

\begin{tabular}{|c|c|c|c|c|c|c|c|c|c|c|}
\hline & $\begin{array}{l}\text { A. affinis } \\
\text { (Uruguay) }\end{array}$ & $\begin{array}{l}\text { A. affinis } \\
\text { (Paraguay) }\end{array}$ & $\begin{array}{c}\text { A. affinis } \\
\text { (Upper Paraná) }\end{array}$ & $\begin{array}{c}\text { A. } \\
\text { ibitiensis }\end{array}$ & $\begin{array}{c}\text { A. } \\
\text { piracicabae }\end{array}$ & Apareiodon sp. & $\begin{array}{c}\text { A. } \\
\text { vitattus }\end{array}$ & $\begin{array}{c}\text { A. } \\
\text { vladii }\end{array}$ & $\begin{array}{c}P . \\
\text { moreirai }\end{array}$ & $\begin{array}{c}P . \\
\text { nasus }\end{array}$ \\
\hline A. affinis (Uruguay) & 0.001 & & & & & & & & & \\
\hline A. affinis (Paraguay) & 0.003 & 0.000 & & & & & & & & \\
\hline $\begin{array}{r}\text { A. affinis (Upper } \\
\text { Paraná) }\end{array}$ & 0.061 & 0.061 & 0.001 & & & & & & & \\
\hline A. ibitiensis & 0.091 & 0.092 & 0.080 & 0.000 & & & & & & \\
\hline A. piracicabae & 0.097 & 0.097 & 0.085 & 0.092 & 0.001 & & & & & \\
\hline Apareiodon sp. & 0.102 & 0.103 & 0.093 & 0.042 & 0.107 & 0.000 & & & & \\
\hline A. vitattus & 0.097 & 0.098 & 0.084 & 0.096 & 0.009 & 0.107 & 0.000 & & & \\
\hline A. vladii & 0.099 & 0.099 & 0.086 & 0.033 & 0.096 & 0.022 & 0.096 & 0.000 & & \\
\hline P. moreirai & 0.153 & 0.153 & 0.156 & 0.146 & 0.137 & 0.143 & 0.133 & 0.136 & 0.001 & \\
\hline P. nasus & 0.146 & 0.146 & 0.153 & 0.147 & 0.140 & 0.142 & 0.136 & 0.137 & 0.007 & 0.000 \\
\hline
\end{tabular}


Table 3. Analysis by nucleotide diagnostic (ND) for the pair of species with divergence lower less than $2 \%$.

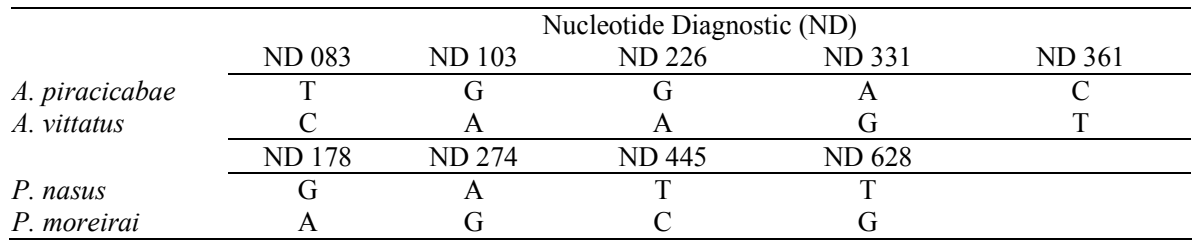

congeneric average of $17.2 \%$, showing a variation of $71 \mathrm{X}$ between the conspecific and congeneric distances (Persis et al., 2009). Pereira et al. (2010) analyzed species from the Paraíba do Sul River basin and found a difference of $79 x$ between the conspecific $(0.13 \%)$ and congeneric species $(10.36 \%)$.

The intraspecific divergence value found in the present study is lower than the values found in the literature for groups of fish, while the value found for congeneric species is consistent with other studies. According to Pereira et al. (2010), this relatively low value may be attributed to the possibility that the analyzed species show a low divergence among conspecific individuals, or to a limited sampling of the genetic variation of the considered species. Thus, even though all species are represented by more than one specimen, it is possible that increasing the number of specimens would lead to an increase in conspecific values.

DNA barcode- based information should not be considered alone, but as an extension of studies in morphology, behavior, geography, and any other attribute of the organism, which can facilitates its identification (DeSalle, 2006). All species analyzed herein with COI (except for the $A$. affinis population from the Uruguay River) and reliably identified have been chromosomically and morphologically characterized, as shown in Table 4. In some cases, cytogenetics and morphology are in agreement in the characterization of species, such as $A$. piracicabae, A. vladii, A. vitattus, P. moreirai, and P. nasus. In other cases, cytogenetics is able to distinguish samples from one species considered by taxonomy as a single entity, for example, the $A$. affinis samples. In this case, DNA barcoding was of great importance for the detection of the putative species (Table 4).

Two pair of species showed low interspecific divergence: A. piracicabae and A. vittatus $(0.9 \%)$ and $P$. moreirai and $P$. nasus $(0.7 \%)$. Although low, these values were enough to discriminate them due to the high difference between the conspecific and congeneric K2P genetic divergences (conspecific values lower than $0.1 \%$ ). Additionally the ND analysis also allowed their discrimination. Interestingly, the pair of the species A. piracicabae and A. vitattus, besides having a low K2P divergence, showed a close relationship confirmed by a phylogeny based on morphological characters (Garavello, 1977; Pavanelli, 1999) and on their chromosomal characteristics (Moreira-Filho et al., 1985; Jesus \& MoreiraFilho, 2000a; Bellafronte et al., 2011) (Table 4). However, besides the similarities, A. piracicabae and A. vittatus are considered valid species. This fact may be related to the emergence of the Iguazu Falls (located in city of Foz do Iguaçu, Paraná State, Brazil), where the fish populations of the Iguaçu River were isolated from those of the Paraná River (Fig. 1). The falls are about $70 \mathrm{~m}$ high (Maack, 1981), and probably allowed the differentiation. As for $P$. nasus and $P$. moreirai, morphologically and chromosomally distinct, the low K2P divergence (Table 4) may indicate that separation of these species at the molecular level did not yet occur, and this may be explained by incomplete lineage sorting. This may have happened because there was not enough time for the separation of these two lineages after the speciation event, i.e., the absence of gene flow must be recent and insufficiency of time for significant mutations to occur, since these species may be found in sympatry and syntopy in the Sapucaí River, type locality of $P$. moreirai (Ingenito \& Buckup, 2005).

In Apareiodon sp., a species very similar to A. ibitiensis, the mean genetic divergence was high enough to differentiate between them (4.2\%). Vicari et al. (2006) chromosomically characterized Apareiodon sp. collected in the Verde River, a tributary of the Tibagi River (Paraná) belonging to the hydrographic system of the upper Paraná River. According to Pavanelli (pers. comm.), it may be a new species of the genus. Cytogenetically, Apareiodon sp. also showed great similarity with $A$. ibitiensis, however with some particularities. Regarding the similarities, both have 54 chromosomes, sharing the same ZZ/ZW single sex chromosome system and the location of the $5 \mathrm{~S}$ rDNA is on the same chromosome pair (pair 9) characterized by the same heterochromatization process (Table 4). Subtle differences are present in the chromosome morphology (A. ibitiensis has 50 meta-submetacentric and 6 subtelocentric chromosomes) and the NORs are single in Apareiodon sp. and multiple in A. ibitiensis (Table 4) (MoreiraFilho et al., 1984, 1985; Jesus \& Moreira-Filho, 2000a; Vicari et al., 2006; Bellafronte et al., 2009). Also, in studies with satellite DNAs, Schemberguer et al. (2011) considered Apareiodon sp. identical to $A$. ibitiensis. Unlike the previous techniques, DNA barcoding was a more effective and definitive methodology for the differentiation of these two species.

In Apareiodon affinis, the COI analysis showed a low divergence among populations of the Uruguay and Paraguay basins $(0.3 \%)$, indicating a greater relationship among them, but also showed a high divergence $(6.1 \%)$ between these two populations and that from the upper Paraná River. Moreover, morphological and cytogenetical divergences are also found (Table 4). This species was described by Steindachner in 1879 with type locality in the La Plata River, province of Buenos 


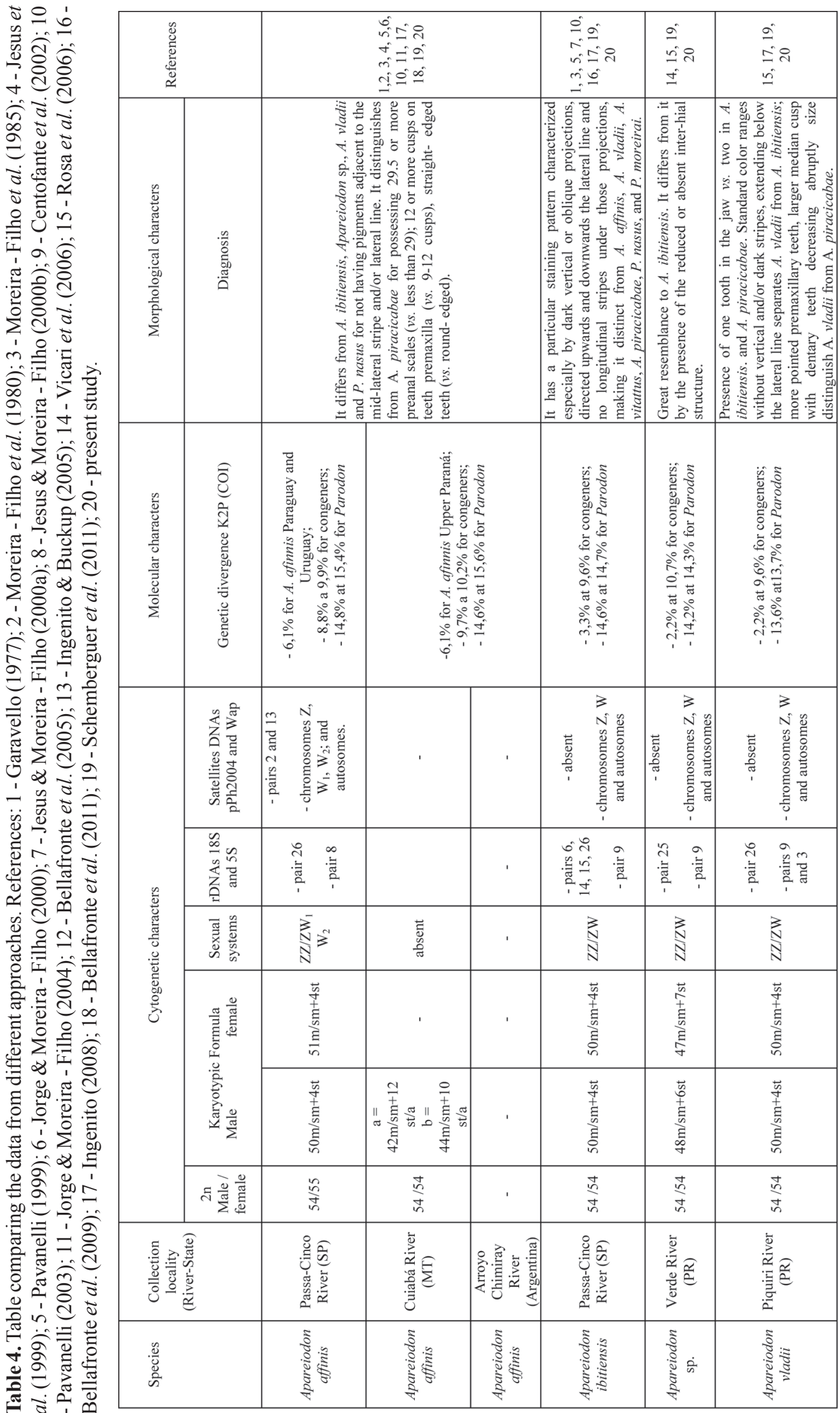




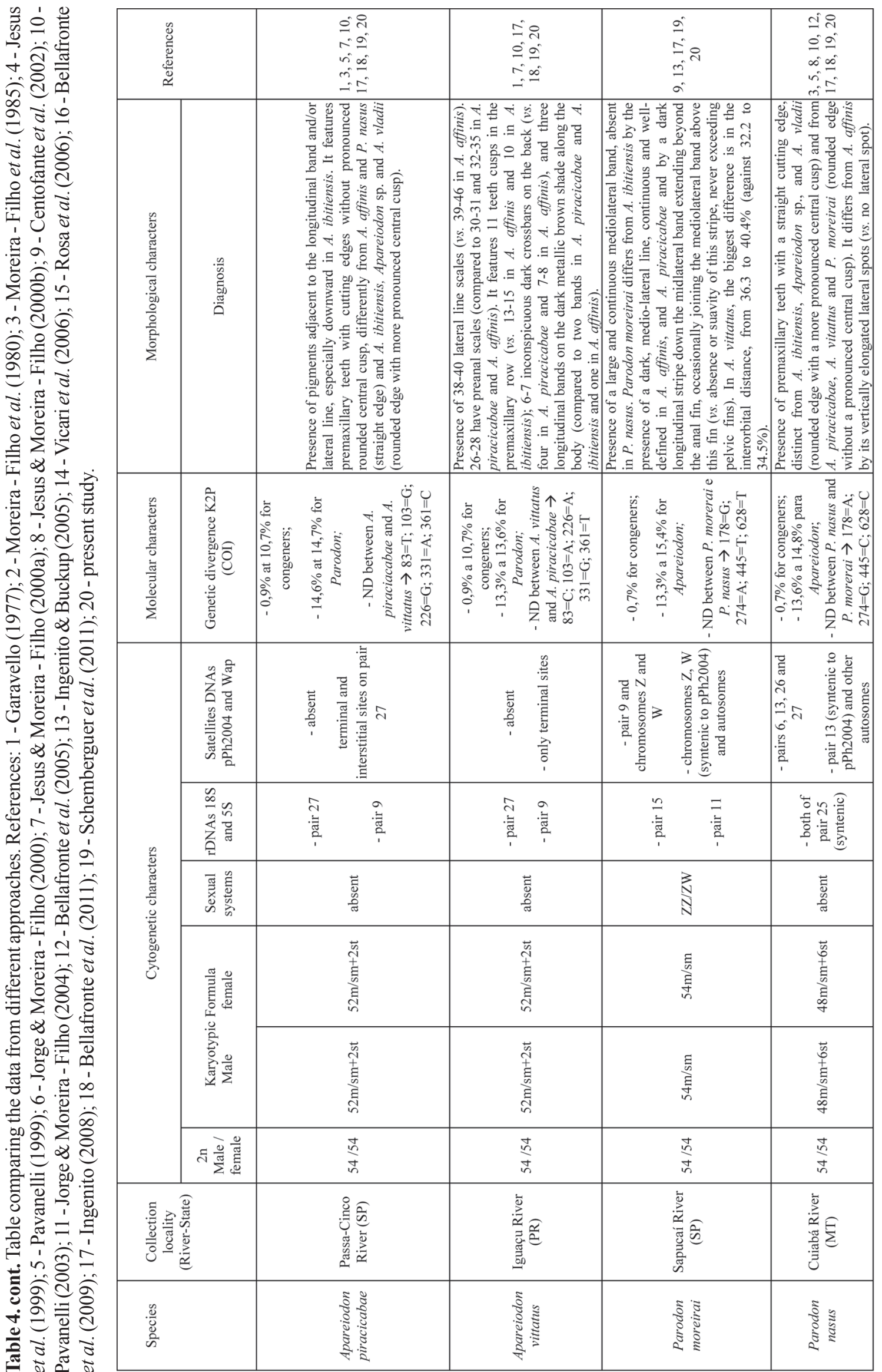


Aires (Argentina) and has a wide geographic distribution, being found in several locations along the La Plata River basin, including the Lower Paraná, Uruguay, Paraguay, and upper Paraná basins (Pavanelli, 2003; Buckup et al., 2007). Although different populations have not shown morphological differences (Pavanelli, 1999, 2003), chromosomal analyses showed differences among the $A$. affinis samples from the lower Paraná River, Paraguay, and upper Paraná basins. While the samples from the lower Paraná and Paraguay show 54 chromosomes, with the presence of acrocentric chromosomes, the upper Paraná sample is composed of 54/55 chromosomes in males and females, respectively, characterizing a $\mathrm{ZZ} / \mathrm{ZW}_{1} \mathrm{~W}_{2}$ multiple sex chromosome system (Table 4). Thus, the high genetic divergence, along with the cytogenetical data, reinforces the probability that the $A$. affinis samples from the upper Paraná are of a distinct group, therefore suggesting a taxonomic revision. Until 1982, before the construction of the Itaipu hydroelectric dam, located in the city of Foz do Iguaçu, Paraná State, Brasil (Fig. 1), the Guaíra Falls, an important geographical barrier, considered the world's largest waterfall by the volume of water, was located in the city of Guaíra, Paraná State (Fig. 1), and acted isolating the majority of the upper Paraná river ichthyofauna from the remaining fauna downstream: lower Paraná/Uruguay/Paraguay basins, including the A. affinis populations (Bonetto et al., 1986; Abell et al., 2008).

Although large migratory fishes were able to cross the Guaíra Falls in both directions, and despite the fact that the damming led to the invasion of essentially sedentary or short-distance migratory species, the upper Paraná River is considered a discrete ichthyological ecoregion (Hubert \& Reno, 2006; Júlio Jr et al., 2009). Regarding the populations from the Uruguay and Paraguay basins analyzed herein, the low divergence observed probably occurred because of the opportunity of dispersal through the La Plata River, an unaltered route in the past 10 million years (Sivasundar et al., 2001).

DNA barcoding, besides discriminating species, is also sometimes able to differentiate higher taxonomic levels such as genera, families, orders and classes, characterized by the constant increase in genetic variation (Hubert et al., 2008). The mean between the genera Parodon and Apareiodon was $14.4 \%$, compatible with a clear separation between them, such as the mean found by Ward et al. (2005) for the genera of Australian marine fish (15.46\%) and Hubert et al. (2008) for the continental freshwater fish from Canada (15.38\%). Therefore, the data presented here suggest that Apareidon and Parodon are distinct units within the family Parodontidae. In this case, chromosomal characters overlap, not being able to sustain a differentiation between the genera.

In summary, the DNA barcode studies provide examples of the usefulness of this methodology to catalog the marine and continental waters fish diversity, since it supports the discovery of probable new species and genera, provides information about species that represent good models for comparative biogeographical studies, and also provides knowledge about the molecular systematics of fish species complexes, contributing to improve the estimates of local species richness, assists in the delineation of taxonomic units for conservation programs and clearly discriminates commercially important fishes (Beheregaray, 2008; Carvalho et al., 2011). In this study, the integrated analysis of morphological, cytogenetical and molecular characters (DNA barcode) was important for the characterization of taxonomically problematic species of Parodontidae. Therefore, these identification systems, as well as others in integrative taxonomy, should not be seen as competitors or exclusive, but as different approaches cooperating to reach the same goal - delimiting species (Dayrat, 2005).

\section{Acknowledgments}

The authors are grateful to Liano Centofante, Alberto Sergio Fenocchio, and Marcelo Ricardo Vicari for the supply of some species, and the Instituto Brasileiro do Meio Ambiente e dos Recursos Naturais Renováveis (IBAMA - License number: 10538-1) for granting authorization for material collection. This study was financed by the Fundação de Amparo à Pesquisa do Estado de São Paulo (FAPESP), Conselho Nacional de Desenvolvimento Científico e Tecnológico (CNPq) Coordenação de Aperfeiçoamento de Pessoal de Nível Superior (CAPES) and the Fundação Araucária (Fundação Araucária de Apoio ao Desenvolvimento Científico e Tecnológico do Estadodo Paraná).

\section{Literature Cited}

Abell, R., M. L. Thieme, C. Revenga, M. Bryer, M. Kottelat, N. Bogutskaya, B. Coad, N. Mandrak, S. L. Balderas, W. Bussing, M. L. J. Stiassny, P. Skelton, G. R. Allen, P. Unmack, A. Naseka, R. Ng, N. Sindorf, J. Robertson, E. Armijo, J. Y. Higgins, T. J. Heibel, E. Wikramanayake, D. Olson, H. L. López, R. E. Reis, J. G. Lundberg, M. H. S. Pérez \& P. Petry. 2008. Freshwater ecoregions of the world: a new map of biogeographic units for freshwater biodiversity conservation. Bioscience, 58: 403-414.

Albert, J., F. M. C. Fernandes-Matioli \& L. F. Almeida-Toledo. 1999. A new species of Gymnotus (Gymnotiformes, Teleostei) from Southeastern Brazil: towards the deconstruction of Gymnotus carapo. Copeia, 1999: 410-421.

Baker, A. M., C. Bartlett, S. E. Bunn, K. Goudkamp, F. Sheldon \& J. M. Hughes. 2003. Cryptic species and morphological plasticity in long-lived bivalves (Unionoida: Hyriidae) from inland Australia. Molecular Ecology, 12: 2707-2717.

Barrett, R. D. H. \& P. D. N. Hebert. 2005. Identifying spiders through DNA barcodes. Canadian Journal of Zoology, 83: 481491.

Beheregaray, L. B. 2008. Twenty years of phylogeography: the state of the field and the challenges for the Southern Hemisphere. Molecular Ecology, 17: 3754-3774.

Bellafronte, E., V. P. Margarido \& O. Moreira-Filho. 2005. Cytotaxonomy of Parodon nasus and Parodon tortuosus (Pisces, Characiformes). A case of synonymy confirmed by cytogenetic analyses. Genetics and Molecular Biology 28, 710-716.

Bellafronte, E., M. R. Vicari, R. F. Artoni, V. P. Margarido \& O. Moreira-Filho. 2009. Differentiated ZZ/ZW sex chromosomes in Apareiodon ibitiensis (Teleostei, Parodontidae): considerations 
on cytotaxonomy and biogeography. Journal of Fish Biology, 75: 2313-2325.

Bellafronte, E., M. O. Schemberger, O. Moreira-Filho, M. C. Almeida, R. F. Artoni, V. P. Margarido \& M. R. Vicari. 2011. Chromosomal markers in Parodontidae: an analysis of new and reviewed data with phylogenetic inferences. Reviews in Fish Biology and Fisheries, 21: 559-570.

Benine, R. C., T. C. Mariguela \& C. Oliveira. 2009. New species of Moenkhausia Eigenmann, 1903 (Characiformes: Characidae) with comments on the Moenkhausia oligolepis species complex. Neotropical Ichthyology, 7: 161-168.

Bickford, D., D. J. Lohman, N. S. Sodhi, P. K. L. Ng, R. Meier, K. Winker, K. K. Ingram \& I. Das. 2007. Cryptic species as a window on diversity and conservation. Trends in Ecology and Evolution, 22: 148-155.

Blaxter, M. 2003. Counting angels with DNA. Nature, 421: 122-124.

Bonetto, A. A. 1986. The Paraná river system. Pp. 541-556. In: Davies, B. R. \& K. F. Walker (Eds.). The ecology of river systems. Dordrecht, Dr. Junk, 793p.

Buckup, P.A., N. A. Menezes \& M. S. Ghazzi. 2007. Catálogo das espécies de peixes de água doce do Brasil. Série livros 23, Museu Nacional, Rio de Janeiro.

Carvalho, D. C., D. A. A. Oliveira, P. S. Pompeu, C. G. Leal, C. Oliveira \& R. Hanner. 2011. Deep barcode divergence in Brazilian freshwater fishes: the case of the São Francisco river basin. Mitochondrial DNA, 22: 1-7.

Centofante L., L. A. C. Bertollo \& O. Moreira-Filho. 2002. A ZZ/ ZW sex chromosome system in a new species of the genus Parodon (Pisces, Parodontidae). Caryologia, 55: 139-150.

Chen, J., Li Q., Kong L. \& Yu H. 2011. How DNA Barcodes Complement Taxonomy and Explore Species Diversity: The Case Study of a Poorly Understood Marine Fauna. Plos One, 6: 1-9.

Dayrat, B. 2005. Towards integrative taxonomy. Biological Journal of the Linnean Society, 85: 407-415.

DeSalle R. 2006. Species discovery versus species identification in DNA barcoding efforts: response to rubinoff. Conservation Biology, 20: 1545-1547

Fernandes, F. M. C., J. S. Albert, M. F. Z. Daniel-Silva, C. E. Lopes, W. G. R. Crampton \& L. F. Almeida-Toledo. 2005. A new Gymnotus (Teleostei: Gymnotiformes: Gymnotidae) from the Pantanal Matogrossense of Brazil and adjacent drainages: continued documentation of a cryptic fauna. Zootaxa, 933: 1-14.

Folmer, O., M. Black, W. Hoeh, R. Lutz \& R. Vrijenhoek. 1994. DNA primers for amplification of mitochondrial cytochrome $\mathrm{c}$ oxidase subunit I from diverse metazoan invertebrates. Molecular Marine Biology and Biotechnology, 5: 294-299.

Garavello, J. C. 1977. Descrição de Apareiodon vittatus sp. n. do rio Iguaçu e comentários sobre as espécies do gênero Apareiodon Eigenmann, 1916 (Ostariophysi, Parodontidae). Revista Brasileira de Biologia, 37: 447-455.

Gibbs, J. 2009. Integrative taxonomy identifies new (and old) species in the Lasioglossum (Dialictus) tegulare (Robertson) species group (Hymenoptera, Halictidae). Zootaxa, 2032: 1-38.

Godfray, H. C. J. 2002. Challenges for taxonomy. Nature, 417: 17-19.

Hajibabaei, M., G. A. G. Singer, E. L. Clare \& P. D. N. Hebert. 2007. Design and applicability of DNA arrays and DNA barcodes in biodiversity monitoring. BMC Biology, 5: 1-15.

Hajibabaei, M., G. A. C. Singer \& D. A. Hickey. 2006. Benchmarking DNA barcodes: an assessment using available primate sequences. Genome, 49: 851-854.
Hall, T. A. 1999. BioEdit: a user-friendly biological sequence alignment editor and analysis program for Windows 95/98/NT. Nucleic Acids Symposium Series, 41: 95-98.

Hebert, P. D. N., A. Cywinska, S. L. Ball, J. R. deWaard. 2003. Biological identifications through DNA barcodes. Proceedings the Royal Society B, 270: 313-321.

Hebert, P. D. N \& T. R. Gregory. 2005. The Promise of DNA Barcoding for Taxonomy. Systematic Biology, 54: 852-859.

Hebert, P. D. N., M. Y. Stoeckle, T. S. Zemlak \& C. M. Francis. 2004. Identification of birds through DNA barcodes. PloS Biology, 2: 1657-1663.

Hubert, N., R. Hanner, E. Holm, N. E. Mandrak, E. Taylor, M. Burridge, D. Watkinson, P. Dumont, A. Curry, P. Bentzen, J. Zhang, J. April \& L. Bernatchez. 2008. Identifying Canadian freshwater fishes through DNA barcodes. PLoS ONE, 3: e2490.

Hubert, N. \& J. F. Reno. 2006. Historical biogeography of South American freshwater fishes. Journal of Biogeography, 33: 1414-1436.

Ingenito, L. F. S. 2008. Análise filogenética da família Parodontidae (Teleostei, Characiformes). Unpublished Ph.D. Dissertation, Universidade Federal do Rio de Janeiro, Rio de Janeiro, 127p.

Ingenito, L. F. S. \& P. A. Buckup. 2005. A new species of Parodon from the Serra da Mantiqueira, Brazil (Teleostei: Characiformes: Parodontidae). Copeia, 2005: 765-771.

Jansen, D. H., W. Hallwach, P. Blandin, J. M. Burns, J. M. Cadiou, I. Chacon, T. Dapkey, A. R. Deans, M. E. Epstein, B. Espinoza, J. G. Franclemont, W. A. Haber, M. Hajibabaei, J. P. W. Hall, P. D. N. Hebert, I. D. Gauld, D. J. Harvey, A. Hausmann, I. J. Kitching, D. Lafontaine, J. F. Landry, C. Lemaire, J. Y. Miller, J. S. Miller, L. Miller, S. E. Miller, J. Montero, E. Munroe, S. R. Green, S. Ratnasingham, J. E. Rawlins, R. K. Robbins, J. J. Rodriguez, R. Rougerie, M. J. Sharkey, M. A. Smith, M. A. Solis, J. B. Sullivan, P. Thiaucourt, D. B. Wahl, S. J. Weller, J. B. Whitfield, K. R. Willmott, D. M. Wood, N. E. Woodley \& J. J. Wilson. 2009. Integration of DNA barcoding into an ongoing inventory of complex tropical biodiversity. Molecular Ecology Resources, 9: 1-26.

Jesus, C. M. \& O. Moreira-Filho. 1999. Comparative cytogenetics in Apareiodon affinis (Pisces, Characiformes) and considerations regarding diversification of the group. Genetica, 105: 63-67.

Jesus, C. M. \& O. Moreira-Filho. 2000a. Cytogenetic studies in some Apareiodon species (Pisces, Parodontidae). Cytologia, 65: 397-402.

Jesus, C. M. \& O. Moreira-Filho. 2000b. Karyotypes of three species of Parodon (Teleostei: Parodontidae). Ichthyological Exploration of Freshwaters, 11: 75-80.

Jorge, L. C. \& O. Moreira-Filho. 2000. Cytogenetic studies on Apareiodon affinis (Pisces, Characiformes) from Paraná river basin: sex chromosomes and polymorphism. Genetica, 109: 267-273.

Jorge, L. C. O. Moreira-Filho. 2004. Nucleolar organizer regions as markers of chromosomal polymorphism in Apareiodon affinis (Pisces, Parodontidae). Caryologia, 57: 203-207.

Julio Jr. H. F., C. D. Tóis, A. Agostinho \& C. S. Pavanelli. 2009. A massive invasion of fish species after eliminating a natural barrier in the upper rio Paraná basin. Neotropical Ichthyology, 7:709-718.

Kimura, M. A. 1980. Simple method for estimating evolutionary rate of base substitutions through comparative studies of nucleotide sequences. Journal of Molecular Evolution, 16: 111-120.

Maack, R. 1981. Geografia Física do Paraná. Rio de Janeiro. J. Olimpio. 
Malhotra, A. \& R. S. Thorpe. 2004. Maximizing information in systematic revisions: a combined molecular and morphological analysis of a cryptic green pitviper complex (Trimeresurus stejnegeri). Biological Journal of the Linnean Society, 82: 219235.

Mallet, J. \& K. Willmott. 2003. Taxonomy: renaissance or Tower of Babel? Trends in Ecology and Evolution, 18: 57-59.

Marcussen, T. 2003. Evolution, phylogeography and taxonomy within the Viola alba complex (Violaceae). Plant Systematics and Evolution, 237: 51-74.

Melo, B. F., R. C. Benine, T. C. Mariguela \& C. Oliveira. 2011. A new species of Tetragonopterus Cuvier, 1816 (Characiformes: Characidae: Tetragonopterinae) from the rio Jari, Amapá, northern Brazil. Neotropical Ichthyology, 9: 49-56.

Meyer, C. P. 2003. Molecular systematics of cowries (Gastropoda: Cypraeidae) and diversification patterns in the tropics. Biological Journal of the Linnean Society, 79: 401-460.

Moreira-Filho, O., L. A. C. Bertollo \& P. M. Galetti Jr. 1980. Evidences for a multiple sex chromosome system with female heterogamety in Apareiodon affinis (Pisces, Parodontidae). Caryologia, 33: 83-91.

Moreira-Filho, O., L. A. C. Bertollo \& P. M. Galetti Jr.1984. Structure and variability of nucleolar organizer regions in Parodontidae fish. Canadian Journal of Genetics and Cytology, 26: 564-568.

Moreira-Filho, O., L. A. C. Bertollo \& P. M. Galetti Jr. 1985. Karyotypic study of some species of family Parodontidae (Pisces-Cypriniformes). Caryologia, 38: 47-55.

Pavanelli, C. S. 1999. Revisão taxonômica da família Parodontidae (Ostariophysi: Characiformes). Unpublished Ph.D. Dissertation, Universidade Federal de São Carlos, São Carlos, $332 p$.

Pavanelli, C. S. 2003. Family Parodontidae (Parodonts). Pp. 46-50. In: Reis, R. E, S. O. Kullander \& C. J. Ferraris (Eds.). Check List of the Freshwaters fishes of South and Central América. Porto Alegre, Edipucrs.

Pereira, L. H. G, G. M. G. Maia, R. Hanner, F. Foresti \& C. Oliveira. 2010. DNA barcodes discriminate freshwater fishes from the Paraíba do Sul river Basin, São Paulo, Brazil. Mitochondrial DNA, 21: 1-9.

Persis, M., A. C. S. Reddy, L. M. Rao, G. D. Khedkar, K. Ravinder \& K. Nasruddin. 2009. COI (cytochrome oxidase-I) sequence based studies of Carangid fishes from Kakinada coast, India. Molecular Biology Report, 36:1733-1740.

Pires, A. C. \& L. Marinoni. 2010. DNA barcoding and traditional taxonomy unified through Integrative Taxonomy: a view that challenges the debate questioning both methodologies. Biota Neotropica, 10: 339-346.

Roberts, T. R. 1974. Osteology and classification of the Neotropical characoid fishes of the families Hemiodontidae (including Anodontidae) and Parodontidae. Bulletin of Museum Comparative Zoology, 146: 411-472.

Rosa, R., E. Bellafronte, O. Moreira-Filho \& V. P. Margarido. 2006. Constitutive heterochromatin, 5S and 18S rDNA genes in Apareiodon sp. (Characiformes, Parodontidae) with a ZZ/ZW sex chromosome system (Pisces, Characiformes, Parodontidae). Genetica, 128: 159-166.
Saitou, N. \& M. Nei. 1987. The Neighbor-Joining method, a new method for reconstructing phylogenetic trees. Molecular Biology and Evolution, 4: 406-425.

Sambrook, J., E. F. Fritschi \& T. Maniatis. 1989. Molecular cloning: a laboratory manual. Cold Spring Harbor Laboratory Press, New York.

Schemberger, M. O., E. Bellafronte, V. Nogaroto, M. C. Almeida, G. S. Schuhli, R. F. Artoni, O. Moreira-Filho \& M. R. Vicari. 2011. Differentiation of repetitive DNA sites and sex chromosome systems reveal closely related group in Parodontidae (Actinopterygii: Characiformes). Genetica, 139:1499-1508.

Sivasundar, A., E. Bermingham \& G. Ortí. 2001. Population structure and biogeography of migratoryfreshwater fishes (Prochilodus: Characiformes) in major South American rivers. Molecular Ecology, 10: 407-417.

Tamura K., D. Peterson, N. Peterson ,G. Stecher, M. Nei \& S. Kumar. 2011. MEGA5: molecular evolutionary genetics analysis using maximum likelihood, evolutionary distance, and maximum parsimony methods. Molecular Biology Evolution, 10: 2731-9.

Toffoli, D., T. Hrbek, M. L. G. Araújo, M. P. Almeida, P. CharvetAlmeida \& I. P. Farias. 2008. A test of the utility of DNA barcoding in the radiation of the freshwater stingray genus Potamotrygon (Potamotrygonidae, Myliobatiformes). Genetics and Molecular Biology, 31: 324-336

Vicari, M. R., O. Moreira-Filho, R. F. Artoni \& L. A. C. Bertollo. 2006. ZZ/ZW sex chromosome system in an undescribed species of the genus Apareiodon (Characiformes, Parodontidae). Cytogenetics and Genome Research, 114: 163-168.

Vicente, V. E., L. A. C. Bertollo, S. R. Valentini \& O. Moreira-Filho. 2003. Origin and differentiation of sex chromosome system in Parodon hilarii (Pisces, Parodontidae). Satellite DNA, G and C-banding. Genetica, 119: 115-120.

Vicente, V. E., C. M. Jesus \& O. Moreira-Filho. 2001. Chromosomal localization of $5 \mathrm{~S}$ and $18 \mathrm{~S}$ rRNA genes in three Parodon species (Pisces, Parodontidae). Caryologia, 54: 365-369.

Ward, R. D., R. Hanner \& P. D. N. Hebert. 2009. The campaign to DNA barcode all fishes, FISH-BOL. Journal of Fish Biology, 74: 329-356.

Ward, R. D., T. S. Zemlak, B. H. Innes, P. R. Last \& P. D. N. Hebert. 2005. DNA barcoding Australia's fish species. Philosophical Transactions of the Royal Society B, 360: 18471857.

Wilson, E. O. 2003. The encyclopedia of life. Trends in Ecology and Evolution, 18: 77-80.

Xia, X. \& Z. Xie. 2001. DAMBE: Data analysis in molecular biology and evoluiton. Journal of Heredity, 92: 371-373.

Submitted January 3, 2013

Accepted May 24, 2013 by Alexandre Hilsdorf Published September 30, 2013 